\title{
Correction to: Evaluation of growth and motility in non-photosynthetic Azospirillum brasilense exposed to red, blue, and white light
}

\author{
Romina Molina ${ }^{1} \cdot$ Gastón López $^{1} \cdot$ Belén Rodríguez ${ }^{1} \cdot$ Susana Rosas $^{1} \cdot$ Verónica Mora $^{1} \cdot$ Fabricio Cassán ${ }^{1} \mathbb{C}$
}

Published online: 17 June 2020

(c) Springer-Verlag GmbH Germany, part of Springer Nature 2020

\section{Correction to: \\ Archives of Microbiology (2020) 202:1193-1201 \\ https://doi.org/10.1007/s00203-020-01829-8}

In the original article, last name and first names of all the authors are inverted. The correct names should appears as "Romina Molina, Gastón López, Belén Rodríguez, Susana Rosas, Verónica Mora, Fabricio Cassán”.

Publisher's Note Springer Nature remains neutral with regard to jurisdictional claims in published maps and institutional affiliations.

The original article can be found online at https://doi.org/10.1007/ s00203-020-01829-8.

Fabricio Cassán

fcassan@exa.unrc.edu.ar

1 Laboratorio de Fisiología Vegetal y de la Interacción

Planta-microorganismo, Universidad Nacional de Río

Cuarto, Ruta 36, Km 601, Río Cuarto, Córdoba, Argentina 